\title{
Two routes to language: stylistic variation in one child*
}

\author{
HILKE ELSEN, Universität München
}

\section{ABSTRACT}

This paper reports the early language development of a Germanspeaking girl who produced referential as well as expressive utterances. Expressive speech style is illustrated by the use of babbling strings with target intonation, universal words, filler syllables, pivot constructions and a smooth transition to syntax. Referential style is characterized by the gradual development of phonology, the gradual elaboration of words, distinct articulation, telegraphic speech and a distinct increase of vocabulary at one point in time. The child produced expressive style, e.g., holistic utterances, in situations of communicative urgency and when dealing with complex linguistic material. It is assumed that the child tried to compensate for poorly developed production capacities when there was too much information to be processed at the same time. Expressive speech served as a conversationmaintenance strategy. It provided the girl with provisional substitutes to maintain conversation and thus had a distinct function for this child.

\section{INTRODUCTION}

When examining the literature on language acquisition we see that different ways to learn and handle words are mentioned. Stern \& Stern (1928) compared their daughter Hilde with their second child Günther. They found that the boy, in contrast to the girl, scarcely produced single words but combined demonstratives with nouns at an early age. $\mathrm{He}$ used universal words (one form 'referring' to everything interesting),

* I am grateful to the editor and two anonymous reviewers for very helpful comments on a previous draft. The preparation of this article was facilitated by a grant from the Freistaat Bayern. Address for correspondence: Hilke Elsen, Rainfarnstr. 45, D-80933 München, Germany. 
jargon (babbling sequences with target intonation contours) and filler syllables, and was sensitive to rhythm and rhyme. He did not try to achieve a correspondence between his utterances and those of adults. For Günther, expressing ideas and feelings seemed to be important, and no energy was left to achieve articulatory correctness (Stern \& Stern 1928).

Nelson (1973) analysed the first 50 words of 18 children and observed that some children tended to learn predominantly general names and to concentrate on formal aspects of language, while others learned more personal-social words and names of people, and were more interested in social interaction. Nelson termed the first group referential, the second expressive. Nelson's expressive children produced phrases at a later stage than referential children and produced fewer phrases before reaching the 50-word vocabulary level. The expressive learners also used more stereotyped phrases and directive expressions. Grammatically complete parts were frequently found in the phrases of expressive learners whereas telegraphic two-word utterances were often produced by referential children. Referential children acquired more words and had higher acquisition rates than expressive children. Furthermore, referential children tended to be firstborn, came from rather well educated families and seemed to be more precocious. Nelson proposed that the differences between referential and expressive children can be seen as a continuum, with only a few children at the extreme ends. In this study, Nelson's measures of styledifference will be discussed.

Peters (1977) mentioned the possibility of different strategies for different situations in one child. Her subject, Minh, used analytic speech, corresponding to referential style, as well as an extremely high number of unintelligible utterances. The latter could be interpreted only with the help of the mother or with context information. He regularly produced certain intonation contours which made his utterances sound target-like. Peters called this kind of speech Gestalt (often labelled holistic processing), corresponding to expressive style. As a substitute for unanalysed parts of sentences, Minh used filler syllables. He was sensitive to rhythm and intonation and produced sentences rather than single. words. Bates, Bretherton \& Snyder (1988) proposed that expressive children typically concentrate on whole forms and broad outlines and deal with details of words and sentences only later. Peters pointed out that Minh used a clear and recognizable speech style, the referential one, in naming situations. The Gestalt speech, however, appeared in communicative contexts. This 'trying-to-take-part' function of expressive style was also mentioned by Bates et al. (1988), who 
investigated whether the same underlying mechanisms could be found continuously in various modules of language over time. The 'twostrand theory', the hypothesis that it is possible to divide children into expressive and referential learners, could not be sustained by their longitudinal data on 27 children, collected at four age levels $(10,13,20$ and 28 months). At least for one group they postulated that their findings pointed to comprehension as an additional factor to referential and expressive style.

Pine \& Lieven (1990) and Pine (1992) criticized the findings of Bates et al. and emphasized 'the dangers of using age-dependent crosssectional measures to investigate style differences so early in language development' (Pine \& Lieven 1990: 631) because of variations in developmental levels. They found that referential vocabulary scores, especially the number of common nouns, did not reflect differences in style. Pine (1992) hinted at possible relationships between the context in which vocabulary is acquired and individual differences in early vocabulary composition.

In summary, there seem to be at least two strategies of how to acquire language. One way is to segment and analyse the units of language first, in order gradually to construct more complex expressions. Another way is holistic processing or expressive speech, in which whole forms are produced first and details are worked out later. The second type of language has often been ignored by researchers because it is frequently unintelligible (Bates et al. 1988, Peters 1977). One aim of this paper is to present data on the expressive speech style of a girl learning German.

Hampson \& Nelson (1993) observed children in free-play and mealsessions at $1 ; 1$ and $1 ; 8$. They found that no child was categorized referential in one and expressive in another situation. Four children at $1 ; 8$ were classified as referential, ten as expressive and four as in between in the play session, but five children were classified differently in the food context. That is, some children switched from expressive or referential style to the in-between classification or vice versa (Hampson \& Nelson 1993). As each session lasted 15 minutes or less, one must take into account that even more variation is possible when larger language samples are obtained. Indeed, most studies try to categorize expressive or referential children and very few consider the interplay of caregiver behaviour or situation and expressive or referential language (cf. Goldfield 1985/86). The child in this study used both referential and expressive speech. A further aim of this paper will be to investigate possible reasons for variation in style. Pine (1992) supposed that functional differences should be viewed as properties of the interaction. 
Similarly, Goldfield (1985/86) assumed, that 'referential and expressive language reflect the kinds of contexts which the child and caregiver jointly construct' (Goldfield 1985/86: 129). Peters \& Menn (1993) indicated that a child's limited attention span in the face of too much information is often restrictive to language acquisition.

In the case of the child to be studied here (Annalena), it will be suggested that the use of style was often functionally determined. She applied expressive speech as a conversation-maintenance strategy which provided her with provisional substitutes when dealing with complex linguistic expressions. She tried to fulfil communicative demands when there was no need, or no processing energy left, to focus on the elaboration of formal aspects. Annalena used expressive speech to maintain and direct interaction. She applied referential speech when talking about things in her surroundings.

Although some investigators criticize the value of maternal report vocabulary data (Pine 1992, but see Pine \& Lieven 1990), they were found useful by others (cf. the work of Bates and colleagues, Hampson \& Nelson 1993). Furthermore, data of diary studies are now widely accepted in the literature. A method of dealing with the problem of functional classification in early vocabularies has also been discussed (cf. Dromi 1987). In spite of unavoidable shortcomings such as the neglect of comprehension data and the impossibility of gaining information on token numbers, we nevertheless use diary data because they are the only source of continuous information on several linguistic aspects over a longer period of time, and thus provide valuable insights into transitional phenomena and possible interrelations between various linguistic and non-linguistic factors of development (cf. Elsen 1994, 1995 , in press).

\section{METHOD}

For this paper data are taken from a diary study of a German-speaking girl, Annalena, an only child. Both parents have university degrees. The mother was the only caretaker and observer-recorder. Notes were collected periodically from birth to the girl's first word at $0 ; 8.23$. Then data on pronunciation and essential linguistic and non-linguistic situations were collected continuously. All new items and novel pronunciations of established items were documented. Imitations were distinguished from deferred imitations and spontaneous productions. Notes were transferred to filing cards twice a day with additional comments on situation, frequency of use and changes in articulation when necessary. The entire corpus was cross-checked three times a 
month. Daily notes ended when Annalena was 2;5 and had completely acquired the phonological system (Elsen 1991). As the mother and child were always together throughout the study, a complete recording of items and phonological development during this period was obtained and the corpus became quite voluminous. Although the study concentrated on phonology, striking facts about situation and referents, comments on frequency and mortality of individual lexical items and notes on morphology and syntax were recorded. Additionally, audiorecordings were taken from the age of $0 ; 4$. Some early audiotaped data were verified by sonagrams and a trained phonetician. Interjudge agreements were over $80 \%$. Audio-recordings, as well as handwritten notes, were used to describe the babbling-period and to allow checks on later development. After 2;5, data were collected periodically. Detailed data on phonological and lexical development are given in Elsen (1991).

\section{RESULTS AND DISCUSSION}

In this section, production data on early phonological, lexical-semantic, morphological and syntactic development are investigated. In each case referential and expressive strategies are found. Various features said to be typical of expressive style are listed and discussed: jargon (babbling strings with target intonation contours), sound play, invention of forms, universal words, filler syllables, relatively low number of general nominals, smooth transition to syntax. Possible reasons for the differences in processing are given.

\section{Jargon, sound play, invention of forms, universal words}

After a period of cooing, vocal play and repetitive babbling, Annalena used some proto-words at the age of $0 ; 8$. She usually produced variegated babbling strings, e.g. [dardmablə...] (0;9). A distinct adultlike prosody was not yet recognizable (cf. Elsen 1991). Clear cases of jargon babbling, although often whispered, emerged at 0;9 in dialogues with her mother, e.g., [dapədedapəd̄] $(0 ; 9.26)$, [dıkwal'əldu] $(1 ; 0.23)$, [dehıjœmbva] (1;0.27), [abd dīmbdədədva) $(1 ; 1.3)$ with German intonation (superscript letters indicate less distinctive articulation). These utterances were used in conversations when 'answering' the mother's questions or remarks. Thus, turn-taking sequences were created.

Until $0 ; 11$, Annalena's production of jargon increased. At the end of $0 ; 11$, when her lexicon contained about 40 words, words outnumbered babbling sequences. At 1;6/1;7, Annalena often uttered long babbling sequences with words in addition to phrases consisting of up to four, 
rarely five words. The girl's language development here was similar to that of Günther (Stern \& Stern 1928). With time, the ratio of babbling to words in a sentence shifted. At 1;8 only parts of some utterances consisted of jargon. At 1;9 sentences contained babbling strings, e.g.

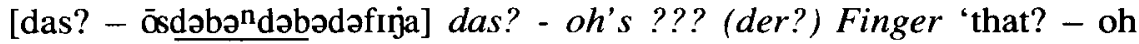
is ??? (the?) finger' $(1 ; 7,23)$; [Хәкōmsdədəvīdadā] der Strom ist ?? wieder da, 'electricity is ?? back again' (1;9) (dots above consonants indicate ambisyllabicity). Often, Annalena produced words or phrases in dialogues and used the last utterance as a model for long jargon strings which gradually grew to songs (sound-play). Finally, during the middle of $1 ; 9$, babbling ceased. The child continued to play with language and make up fantasy-songs.

If Annalena lacked a lexical item she formed one, e.g., [bagba] for ducks $(0 ; 11.15)$, or [boa], articulated with a hoarse voice, for crows (0;11.15). Similar to Günther (Stern \& Stern 1928), her vocabulary included several onomatopoeic words, even a kind of sniffing for hares and rabbits $(0 ; 10-1 ; 2)$ (cf. Elsen 1994). Some of her inventions could not be related to words, e.g., [doIke] $(0 ; 10)$, [geko] $(0 ; 11)$, which were successfully applied in conversations to refer to a toy woodpecker, or [buti] $(1 ; 11.19 \mathrm{ff}$.), for which the meaning could not be traced. When asked the names of the children she had drawn, she immediately

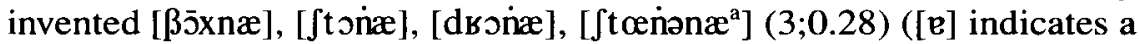
more than half-open central vowel.).

Initially, the girl used structure and sound detached from meaning as a means to maintain conversations (cf. Peters 1977). Her limited vocabulary prevented her from articulating words as quickly and as suitably as needed. Therefore, she created utterances. A comparable strategy was to answer her mother's comments with [da] at approximately 0;9, similar to Günther's $j a$ (Stern \& Stern 1928). This was a precursor of the demonstrative $d a$, 'there', which was used to keep dialogues going and enabled the construction of several turntaking sequences. Some weeks later Annalena, like Günther, produced universal words to label everything interesting: Mama, 'mummy' $(0 ; 11)$, Bild, 'picture' $(0 ; 11)$. In general, however, her phonological system developed gradually and was comparable to that of other referential children. Early sounds and sound combinations were avoided with the help of deletion, substitution, reduplication, occlusion, assimilation, metathesis, vowel-epenthesis, often resulting in resyllabication. The number of sounds and syllables and syllabic complexity grew steadily (cf. Elsen 1991).

We see that Annalena used sounds very early in (proto-) communications. When linguistic abilities increased, the proportion of 
jargon in dialogues and sentences gradually decreased. To keep conversations going, i.e., applying language in correct and required circumstances, she often used invented utterances. She made up lexical items when target words were not at hand or were too difficult to manage (cf. Elsen 1994). Thus, she was almost always successful in talking about her topics with the help of expressive speech as a provisional substitute. The need to participate in 'conversation' was strong. Producing any sound seemed to be better than remaining silent. As Bates et al. (1988) remark, often children talk for the sake of talking. As Annalena's linguistic abilities increased, empty sound was less often required as a substitute and was used only in sound play.

\section{Filler syllables}

To accommodate the rhythmic patterns of her mother tongue, Annalena - similar to Minh (Peters 1977) and Günther (Stern \& Stern 1928) used filler syllables and filler words consisting of sounds from the surrounding text as a substitute for unanalysed or unmemorized parts in children's songs and rhymes. She thereby succeeded in producing the target number of syllables and in placing stress correctly $(\mathrm{la}-\mathrm{h})([\mathrm{n}]$ means the syllabic nasal).

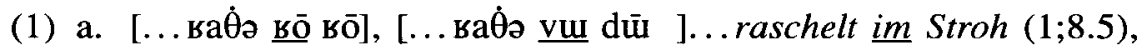
$(1 ; 8.23)$

'rustles in the straw'

b. [lop lop lop fed̄en lıja lop] Hopp, hopp, hopp, Pferdchen lauf Galopp (end of $1 ; 10$ )

'hop hop hop horsie go gallop'

с. [вıglain sı́glaın dū $\underline{\bar{v}}$ vanda] Ringlein, Ringlein, $d u \underline{m u ß t}$ wandern $(1 ; 11.9)$

'little ring, little ring, you must wander on'

d. [bsū ta jakō vīla don $\int$, vīla don $\left.\int\right]$ Bruder Jakob, schläfst du noch, schläfst du noch $(1 ; 11.5)$

'brother Jack, are you sleeping, are you sleeping'

(the song ends ding ding dong; perhaps [vīla don $\left.\int\right]$ means viele Dongs, 'many dongs', and the child contracted the song)

e. ['ā bē $\theta \bar{e}$ kat sə nəṅə nē] $A B C$, die Katze lief im Schnee $(1 ; 11.5)$

'ABC, the cat ran in the snow'

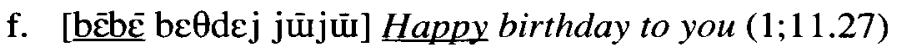




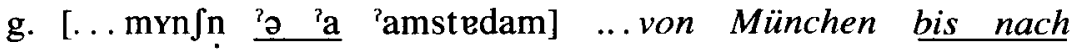
Amsterdaim $(2 ; 1.27)$

'from Munich to Amsterdam'

h. $\left[\ldots \bar{u}^{2} \underline{\mathbf{u}}^{2}\right.$ anien $] \ldots z u \underline{\text { dem }}$ andern $(2 ; 1)$

'to the other one'.

For unanalysed parts of sentences Annalena used filler syllables. At an early age, fillers were often approximations of some neighbouring sounds $(2 \mathrm{a}-\mathrm{c})$.

(2) a. ['but It I 'ta] kaputt ist die da $(1 ; 3.11)$

'this one is broken'

b. ['bapaisı 'sa] Papa ist nicht da (1;3.12)

'daddy is not there'

c. [dədədas?], [dəṡadas?] was ist das? $(1 ; 5)$

'what's that?'

Latcr, scieral examples of [ờ], [ḋ] were funnd. The uiterdıcte contexts in which these were produced indicate that these may have been precursors of the definite article, which has many forms in German (3 a-f). Occasionally, Annalena used [ə], [e], etc., which resemble the prefix for participles ge $(3 \mathrm{~g}-\mathrm{i})$. More about the use of filler syllables as protomorphemes is found in Peters \& Menn (1993). It is important to note that in the part of Germany in which Annalena lives, articles are usually placed before proper names.

(3) a. [ [ِ fant ðıt $\theta$ ] der Elefant sitzt $(1 ; 7,4)$

'the elephant is sitting'

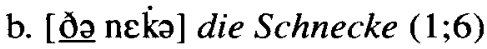

'the snail'

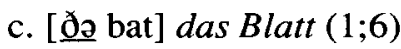

'the leaf'

d. [Do papa zainz] dem Papa seins $(1 ; 7: 11)$

'the father's one'

e. [모 mama lêft da] die Mama schläft da $(1 ; 6.5)$

'the mummy is sleeping there'

f. [da də bapa vīde] da (ist) der Papa wieder $(1 ; 5.30)$

'there the daddy (is) (back) again' 
g. [de papa 'ēmaxt?] der Papa gemacht? (?)

'(what has) the daddy done?'

h. [hap̣ōzēn kōnvēkf] hab' gesehn Cornflakes $(1 ; 10.19)$

'(I) have seen cornflakes'

i. [pat kìtsıa in 'ūa laupḡgêt] Patrizia in Urlaub 'gegeht' $(2 ; 1,22)$

'P. (is) "goed" on holiday'.

With the exception of (1d), all substituted syllables were unstressed and preceded a stressed one. Sometimes the filler syllables were not interpretable (4 a-b).

(4) a. [ndnbodñ gaī] ?? Boden kalt $(1 ; 6,0)$

'?? ground cold'

b. ['agē $\underline{\overline{\mathrm{m}}}$ wœvl] André ?? Löffel $(1 ; 5,5)$

'André ?? spoon'.

Further fillers in sentences (mainly at $1 ; 6 / 1 ; 7$ ) were [dabada], [dabəda], etc., (cf. Peters 1977$)$, or $\left[1^{2} \mathrm{dl}^{2} \mathrm{dl}{ }^{2} \mathrm{dl}\right]$, e.g., [darviadavodō] drei vier ??? 'three four ???', meaning 'many' (1;7.23). Annalena often put [ðəðə], [dədə], [drdr], [mələ] at the beginning of sentences. These nonsense syllables appeared to be vestigial traces of by now diminishing jargon. Similarly, Günther often produced [ə], which he used as a substitute for particles, articles, unstressed prefixes and conjunctions. He even used the sound in places where no word or sound was needed (Stern \& Stern 1928, and cf. Peters \& Menn 1993).

In addition to omitting unstressed syllables, Annalena replaced them with [a] or [ldl], etc., word-initially. They sometimes contained target sounds, e.g., [deldld... dē] André (name) (1;3.12), [ldl... Jan] verloren 'lost' $(1 ; 6 / 1 ; 7)$, [lōdletə] Toilette 'toilet' $(1 ; 9.15)$, [k|k]gāmə] Reklame

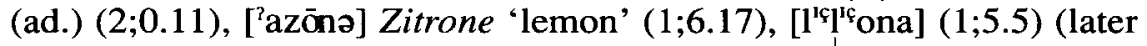
often ['alōnə]) Melone 'melon', ['adǣna] Laterne 'lantern' (1;5.6), and ['aboada] Transporter (lorry) $(1 ; 4 / 1 ; 5)$. This was similar to Amahl's [ri] as first syllable in, e.g., attack, exhaust, conductor, infection (Smith 1973) or Edmond's [ā] for the initial syllable in French costume 'dress', éponge 'sponge' (Grégoire 1937). Note that the substituted syllables in all three languages are not stressed and precede a stressed syllable. Obviously, children at an early age cannot cope with long forms and instead master less salient parts of words with easily manageable universal syllables to maintain syllable number and position of stress.

Annalena also added [aja], [ala], [alal], etc., to the first syllable of a 
three syllable item with initial stress. At 1;4/1;5 she uttered forms such as [metajaI] Schmetterling 'butterfly', [bü̈aja] Hubschrauber 'helicopter', [mıçajar] Michael (name), [hüajar] Hustensaft 'cough syrup', [benajar] Benjamin (name), [aufajar] aufräumen 'to tidy up'; at 1;6 [kıs̄ajar] Christian (name, brother of Benjamin); at 1;8 [dìtsajar] Patrizia (name), deleting the first (unstressed) syllable. She produced too many syllables in ['Italalala] Gießkanne 'watering can', [mōtajaja] Motorrad 'motor-bike', [debəlaja] Zeppelin, [wIlaja] Zwieback 'biscuit', and even [miçajajajajar] Michael (name), when she was excited and urgently awaiting him. Fillers were used as the general last part of a word following the stressed syllable.

To maintain syllable number and rhythm Annalena not only used filler syllables but also reduplicated parts of the word, e.g., [maməmaməlādə] Brombeermarmelade 'blackberry jam' '(2;0.24), [maniımaniı] Badewanne 'bath-tub' (1;6.3), [balbaiō], [babaīō]

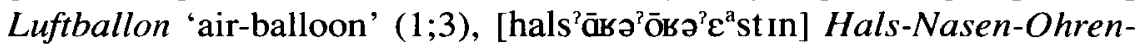
Ärztin 'lady-otolaryngologist' (2;4.17), [ðuðūbaum] Purzelbaum 'somersault' ( $1 ; 9.15)$, [sōnsanja] Lasagne (Italian dish) $(2 ; 4.2)$.

Sometimes the girl mainly remembered rhythm. Some sounds were omitted, for others the exact position was lost, but position of stress and syllable number were correct (cf. Sophie in Fletcher 1985). This was recorded in [malate] Tomate 'tomato' (1;3.12), [vutatak] Hustensaft 'cough syrup' $(1 ; 4.18)$, [gīnana] Gießkanne 'watering can' $(1 ; 4.27)$, [taksono] Taschentuch 'hanky' (1;6.4), [menama] Melanie (name) (1;6.11), [daI'lus] Reißverschluß 'zipper' (1;8.13), [dabəodōl] Sanostol (a vitamin-syrup) (1;9.5), [sctətə]] Cassette 'tape' $(2 ; 0.4)$, [komtarak] Kontrabaß 'contrabass' (2;0.22), [вalalōlī] Ravioli (Italian dish) $(2 ; 1.10)$, [mعlōnī] Memory (game) $(2 ; 3)$, [sasjanə] Lasagne (Italian dish) $(2 ; 4.2)$, [ākokāno], [ābogāno], [āfofāno] Oregano (Italian herb) $(2 ; 5.28)$. With the exception of 'tomato' and probably 'hanky', these expressions are not everyday words and most of them belong to the periphery of the German lexicon. They are structurally complicated, as the typical, i.e., most frequent, German word-pattern consists of two syllables with penultimate stress. The latter were handled by Annalena more easily and with more accuracy.

More complex structures were attempted and achieved, uttered with the help of filler syllables and reduplications serving as substitutions similar to those observed in sentences. Usually, the stressed syllable was retained. As Vihman (1981) proposed, segments in stressed syllables are more salient to children. She reported the same desire to retain syllable number and position of stress and found these factors to be the first to be managed in language acquisition. Similarly, Peters \& 
Menn (1993) described prosodic acoustic features which an expressive child used as a 'starter' when faced with too much information to process at the same time. They called them 'phonological toeholds'. Annalena is a musical child. Similar to Günther and Minh she showed sensitivity to the rhythmic pattern of a word. She tried to maintain syllable number, structure and stress at the expense of individual sounds especially in the case of sentences and complex words. According to Peters \& Menn (1993) this seems to be typical of expressive children. Another feature of expressive language as used by Annalena is pronunciations across word tokens which were variable for early productions of target words.

Furthermore, the child made use of referential style (analytic processing) for shorter words, naming things and when 'reading' a book, and succeeded in building up words gradually and in articulating distinctly (cf. Peters 1977), as described in Elsen (1991).

The use of the expressive strategy may be due to the complexity of long utterances which could not yet be mastered. Annalena was able to cope with one- and two-syllable words. At an early age, she handled nearly all segments of shorter words simultaneously. Longer words were treated more superficially. The phonological system was not yet fully developed. Task complexity and processing capacity interfered. Again, the need to talk was stronger than the need to pronounce correctly. To compensate for poorly developed linguistic capacities the child produced patterns that only roughly corresponded to target items, similar to the expressive children in Peters (1977), Peters \& Menn (1993), Stern \& Stern (1928), Vihman (1981). As Annalena did not apply these strategies in all situations or for all words, they obviously served to provide her with provisional substitutes that enabled the child to take part in the 'language-game' when there was too much information to process at the same time.

\section{Number of general nominals}

Nelson (1973) reported the tendency of her expressive children to learn, initially, more words for expressing feelings and directing people. Although both expressive and referential children had object words in their 50-word-vocabularies, expressive children had a higher proportion of functional words, pronouns, modifiers, personal-social words, and a low proportion of general nominals compared with referential children (Nelson 1973). Annalena's first 50 words are listed in the Appendix, together with some proto-words, which were forms connected with communicative functions rather than with special meanings.

Among Annalena's first ten words were three general object words, 
two specific nominals, three action words and two personal social words (terms adapted from Nelson 1973). Thus, her lexicon contained $33 \%$ general nominals which corresponds to Nelson's findings for expressive children. Annalena's first 20 words contained 9 general nominals. The use of these early lexical items has been described in Elsen (1994). The number of general nominals rose: the second 20 words contained 15 general nominals. The first 50 words, at 1;0.8, consisted of 31 general nominals. The portion of content words had doubled, so that the child could no longer be classified as expressive according to Nelson. Pine \& Lieven (1990) hold that the proportion of nominals always increases with vocabulary size independent of style. It seems that such an analysis does not provide relevant information. The proportion of common nouns as a measure of style-difference should be interpreted with caution because it is a feature of vocabulary acquisition which cuts across rather than reflects differences in strategy' (Pine \& Lieven 1990: 627). In fact, Bates, Marchman, Thal, Fenson, Dale, Reznick, Reilly \& Hartung (1994) reported distinct changes in lexical acquisition for their children (age $0 ; 8$ to $1 ; 4$ ) in addition to great individual differences. If we assume that stylistic variation depends on situation and not on the individual child, then such calculations would not be relevant.

\section{Transition to syntax}

Nelson (1973) found a distinct acceleration in lexical growth, usually termed vocabulary spurt, for her referential children. Using the criterion of 10 phrases as a norm, Nelson showed that expressive children produced longer phrases at an earlier age than referential children. She observed that expressive children tended to use grammatically complete units, whereas referential children usually built telegraphic two-word constructions. The transition from single- to multi-word utterances tended to be a smooth one for expressive children and more abrupt for referential children.

Amalgams On the threshold to syntax Annalena used amalgams, a feature typical of expressive children. [data] das da 'that there' was used as a demonstrative from the beginning of $0 ; 10$. [getıç], [gēniz], [gëiç], etc., geht nicht! 'doesn't work!' appeared at 1;3.19. [zīsta] siehste! 'you see, didn't I tell you!' appeared at 1;6.4 and was often applied to mean 'look!' at 1;6/1;7. [manic] mag nicht '(I, he, she) don't want' was used to indicate refusal. No analytic structure of item and negation can be assumed because the amalgam differed in pronunciation from the positive [maxə], [makə] mag 'I want/like', 
$(1 ; 6-1 ; 8)$. [dədə'das], [dəs่ə'das] das ist das? 'that is that?', meaning 'what is that?', was noted at $1 ; 5$.

Vocabulary spurt In Fig. 1 the accumulation of words is documented, beginning with the day Annalena produced her first word $(0 ; 8.23)$. The total number of words in the cumulative lexicon was calculated each third of the month (see section on Method). A vocabulary spurt was recorded six months after the onset of speech, when, after a period of acquiring about two new items a day, the child began to add three, four or more new words daily to her lexicon.

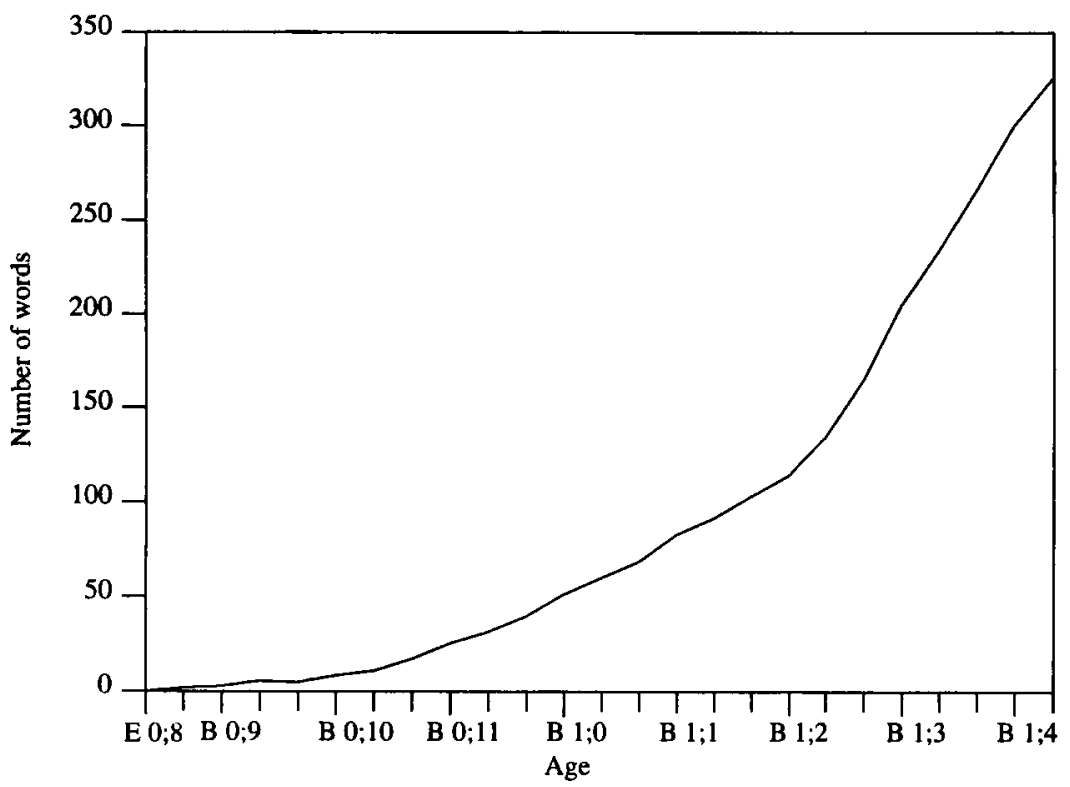

Fig. 1. Annalena's early cumulative lexicon. The total number of words was calculated three times a month, for the first ten days, for the second ten days and for the rest of a month. $B$ means beginning and covers the first ten days of a month. At the end (E) of 0.8 , the child's lexicon contained two words.

Early word combinations Three months after her first word, Annalena produced her first two-word utterances. One month later, Annalena frequently produced two-word utterances and occasionally three-word phrases. These usually, but not always, consisted of [da] da 'there', followed by a noun. Occasionally, Annalena reversed the order, used 
words other than nouns or the amalgam [data], [dəta], etc., das da 'that there' rather than [da]. At the age of 15 months, most words were embedded in constructions. Towards the end of 15 months, multi-word utterances consisted of various words. Thus Annalena, like Günther (Stern \& Stern 1928: 87), made a transitional step between single- and multi-word utterances in building mainly $d a+$ single-word constructions or combinations with [a] auch 'also, too' before using free combinations frequently.

The transition from single- to multi-word expressions was not very clear-cut for this child (cf. Elsen 1995). Expressive as well as referential strategies were found. The child used amalgams, pivotconstructions and holistic sentences and, simultaneously, telegraphic speech with gradually increasing complexity. Thus, sentences such as (5) as well as (6) were found, all meaning 'daddy is not there'.

(5) a. ['bapaișiś'

b. ['bapalzız'da] $(1 ; 3.18)$

c. [bapadıtā], [pabatittā] etc., often at $1 ; 3 / 1 ; 4$

(6) a. [nain bapa] nein Papa (1;3.16)

'no daddy'

b. ['papə da 'nain] Papa da nein (1;3.25)

'daddy there no'

c. [bapa] + 'all-gone' gesture $(1 ; 4.10)$

(7) a. [papa Ist dā!] Papa ist da! $(1 ; 6.12)$

'daddy is there!', when he is coming home

b. [vō bıstu papa?] Wo bist du, Papa? (1;6.21)

'where are you, daddy', when looking for him.

The child displayed features that are typically associated with expressive and referential children. It may be assumed that as long as the child's analytic linguistic abilities were poorly developed and allowed only short utterances she often made use of expressive style (holistic formations) because conveying her message was more important than utilizing the correct form of the expression. Exact processing occurs when linguistic proficiency is attained ( $7 \mathrm{a}-\mathrm{b})$ (cf. Peters \& Menn 1993). Again, the use of expressive utterances as provisional substitutes to maintain conversation seems probable. 
Furthermore, Annalena showed a lexical spurt, which is said to be typical of referential children. That there was no relation between vocabulary growth and syntactic development was already shown in Elsen (1995). Vocabulary growth as a measure of style should be reconsidered or even abandoned if one assumes that there are situationally dependent language styles. However, no implications are made that exclude interrelations between vocabulary growth and number of nominals (cf. Goldfield 1990).

\section{CONCLUSION}

In summary, the child considered here showed typical features of both referential and expressive children. On the one hand she is an only child, female and precocious (first word at $0 ; 8.23,50$ words at $1 ; 0.8$ ). Annalena used single words, usually distinctly pronounced, and elaborated them gradually, often with the help of imitation. She applied highly intelligible telegraphic speech. These are all features representing referentiality. On the other hand, the girl produced expressive speech: jargon, filler syllables, amalgams, and pivot constructions. Two further measures for stylistic variation described in the literature, ratio of general nouns and vocabulary growth, were not found useful.

When examining the situations in which expressive utterances appeared, one finds two recurring causes. The linguistic material which the child was required to master was too complex to be processed instantaneously. Alternatively, or additionally, the situation did not allow prompt and complete processing because the child chose to meet conversational demands first. In both cases Annalena preferred incomplete production to staying silent or interrupting the flow of conversation. As Gopnik (1988) pointed out, very young children use language primarily as a social-communicative tool. For Annalena, expressive strategies served as a conversation-maintenance mechanism and thus can be said to be functionally determined. It should be stressed, however, that Nelson, when discussing styles, never claimed that children can be invariably allocated to one category or another. Our findings, then, should help us to uncover how the two may interact.

The diary data provided here are limited and they show the development of one child. Nevertheless, it should be revealing to compare them with further detailed samples to investigate the variation and interaction of language styles in other children, something universalist models tend to ignore. One aim of future research should be to describe and understand stylistic variation on the basis of data on 
various linguistic domains and conversational background. With the help of functionally oriented approaches, which view language as a communicative social action, we hope we will understand not only exactly what children say but why.

\section{REFERENCES}

Bates, E., Bretherton, I. \& Snyder, L. (1988). From First Words to Grammar (Cambridge: Cambridge University Press).

Bates, E., Marchman, V., Thal, D., Fenson, L., Dale, P., Reznick, J. S., Reilly, J. \& Hartung, J. (1994). Developmental and stylistic variation in the composition of early vocabulary. Journal of Child Language, 21, 85-123.

Dromi, E. (1987). Early Lexical Development (Cambridge: Cambridge University Press). Elsen, H. (1991). Erstspracherwerb (Wiesbaden: DUV). (1994). Phonological constraints and overextensions. First Language, 14, 305-15.

- (1995). Linguistic team-work - the interaction of linguistic modules in first language acquisition. Paper presented at the 27th annual meeting of the Child Language Research Forum, Stanford 1995 (to appear in E. Clark (ed.), The Proceedings of the Twenty-seventh Annual Child Language Research Forum (Stanford: CSLI Publications)).

- (in press). Der Aufbau von Wortfeldern. Lexicology, 1 (2).

Fletcher, P. (1985). A Child's Learning of English (London: Basil Blackwell \& André Deutsch).

Goldfield, B. A. (1985/86). Referential and expressive language: a study of two motherchild dyads. First Language, 6, 119-31.

- (1990). Pointing, naming, and talk about objects: referential behaviour in children and mothers. First Language, 10, 231-42.

Gopnik, A. (1988). Three types of early word: the emergence of social words, names and cognitive-relational words in the one-word stage and their relation to cognitive development. First Language, 8, 49-70.

Grégoire, A. (1937). L'Apprentissage du langage (Liège/Paris: Librairie Droz).

Hampson, J. \& Nelson, K. (1993). The relation of maternal language to variation in rate and style of language acquisition. Journal of Child Language, 20, 313-42.

Nelson, K. (1973). Structure and strategy in learning to talk. Monographs of the Society for Research in Child Development, 38 (1-2), 1-135.

- (1985). Making Sense (New York: Academic Press).

Peters, A. M. (1977). Language learning strategies: does the whole equal the sum of the parts? Language, 53 (3), 560-73.

Peters, A. M. \& Menn, L. (1993). False starts and filler syllables: ways to learn grammatical morphemes. Language, 69 (4), 742-75.

Pine, J. M. (1992). The functional basis of referentiality: evidence from children's spontaneous speech. First Language, 12, 39-55.

Pine, J. M. \& Lieven, E. V. M. (1990). Referential style at thirteen months: why agedefined cross-sectional measures are inappropriate for the study of strategy differences in early language development. Journal of Child Language, 17, 623-31.

Smith, N. V. (1973). The Acquisition of Phonology - a Case Study (Cambridge: Cambridge University Press).

Stern, C. \& Stern, W. (1928). Die Kindersprache (Darmstadt: Wissenschaftliche Buchgesellschaft), reprinted 1965.

Vihman, M. M. (1981). Phonology and the development of the lexicon: evidence from children's errors. Journal of Child Language, 8, 239-65. 
APPFNDIX

ANNALENA'S FIRST 50 WORDS

\begin{tabular}{|c|c|c|c|c|}
\hline No. & Age & $\begin{array}{l}\text { Child's form } \\
\text { (example/s) }\end{array}$ & Target & Meaning (roughly) \\
\hline & $0 ; 8$ & al & & general delight \\
\hline & $0 ; 8$ & $\mathrm{da}$ & (da) & $\begin{array}{l}\text { demonstrative, (later general } \\
\text { acknowledgement/turn) }\end{array}$ \\
\hline & $0 ; 8$ & dətə & (das da) & demonstrative \\
\hline 1 & $0 ; 8.23$ & nain & nein & no \\
\hline 2 & $0 ; 8.25$ & mama & Mama & mummy \\
\hline 3 & beg. $0 ; 9$ & da & da & there \\
\hline 4 & beg. $0 ; 9$ & baba & Papa & daddy \\
\hline 5 & mid. $0 ; 9$ & ar! & ei! & $\begin{array}{l}\text { (when fondling, special } \\
\text { intonation) }\end{array}$ \\
\hline 6 & mid. $0 ; 9$ & aI & $\mathrm{Ei}$ & egg \\
\hline 7 & beg. $0 ; 10$ & data & das da & that (one over there) \\
\hline 8 & beg. $0 ; 10$ & bita & bitte & please, here you are \\
\hline 9 & beg. $0 ; 10$ & pIpI & piepiep & mouse \\
\hline 10 & $0 ; 10.13$ & $\mathrm{~d} \varepsilon \mathrm{d} \varepsilon, \mathrm{t} \varepsilon \mathrm{d} ə$ & Teddy & teddy bear \\
\hline \multirow[t]{2}{*}{11} & $0 ; 10.16$ & $\mathrm{~b}, \mathrm{ba}$ & Buch & book \\
\hline & $0 ; 10.24$ & 'sniff'a & & hare/rabbit \\
\hline 12 & $0 ; 10.28$ & mom, bau & Baum & tree \\
\hline 13 & $0 ; 10,28$ & pōp! & tööt! & $\begin{array}{l}\text { toot! (when nudging the } \\
\text { nose) }\end{array}$ \\
\hline 14 & $0 ; 10.28$ & nana $^{b}$ & Zahnbürste & toothbrush \\
\hline 15 & $0 ; 10.28$ & nana & Annalena & (child's own name) \\
\hline 16 & $0 ; 10 / 0 ; 11$ & dada! & Tag! & hello! \\
\hline 17 & beg. $0 ; 11$ & ja & ja & yes \\
\hline 18 & beg. $0 ; 11$ & $\mathrm{bm}^{\mathrm{c}}$ & brumm & car \\
\hline 19 & $0 ; 11.3$ & aðða $^{d}$ & Essen & to eat/meal \\
\hline 20 & $0 ; 11.3$ & bI & Bild & picture \\
\hline 21 & $0 ; 11.3$ & vava & wauwau & dog \\
\hline 22 & $0 ; 11.6$ & ata, ada! & ada! & bye (dialectal) \\
\hline 23 & $0 ; 11.8$ & man! & Mann! & (when annoyed, indignant) \\
\hline 24 & $0 ; 11.10$ & kīkïi & kikeriki & cock \\
\hline 25 & $0 ; 11.11$ & bal & Ball & ball \\
\hline 26 & $0 ; 11.11$ & bal & Lampe & lamp \\
\hline 27 & $0 ; 11.15$ & $\operatorname{man}$ & Mann & man, male \\
\hline 28 & $0 ; 11.15$ & pIpI & pieppiep & bird (not duck or crow) \\
\hline 29 & $0 ; 11.15$ & bagba & & duck, goose \\
\hline
\end{tabular}

continued overieaf . . 


\begin{tabular}{llll}
\hline No. Age & $\begin{array}{l}\text { Child's form } \\
\text { (example/s) }\end{array}$ & Target & Meaning (roughly) \\
\hline
\end{tabular}

\begin{tabular}{|c|c|c|c|c|}
\hline 30 & $0 ; 11.15$ & boa & & crow \\
\hline 31 & $0 ; 11.15$ & nanə & Banane & banana \\
\hline 32 & mid. $0 ; 11$ & $\mathrm{dē}$ & Tee & tea \\
\hline 33 & $0 ; 11.18$ & gInge & trinken & to drink \\
\hline 34 & $0 ; 11.23$ & hat & heiß & hot \\
\hline 35 & $0 ; 11.24$ & ba, baI & Wasser (?) & water \\
\hline 36 & $0 ; 11.27$ & baba & Bauch & belly \\
\hline 37 & $0 ; 11.29$ & meInว & miau (?) & cat \\
\hline 38 & $0 ; 11.30$ & de & Zeh & toe \\
\hline 39 & $0 ; 11.30$ & bebI & Baby & baby \\
\hline 40 & $0 ; 11.30$ & gçî ${ }^{\mathrm{d}}$ & kalt & cold \\
\hline 41 & beg. $1 ; 0$ & mom! & bong! & $\begin{array}{l}\text { (something sudden, } \\
\text { unexpected like collisions) }\end{array}$ \\
\hline 42 & beg. $1 ; 0$ & bam, mom! & bimbam! & ding-dong (swinging) \\
\hline 43 & beg. $1 ; 0$ & o, эI! & oh! & oh! \\
\hline 44 & $1 ; 0.2$ & $\overline{\mathbf{B}}$ & Rohr & tube \\
\hline 45 & $1 ; 03$ & anl & Öl & oil (for cleaning) \\
\hline 46 & $1 ; 04$ & $b^{\prime} b^{-i^{i}}$ & Papier & paper \\
\hline 47 & $1 ; 0.5$ & pipī & Pipi & urine \\
\hline 48 & $1 ; 0.5$ & anl & Eule & owl \\
\hline 49 & $1 ; 0.5$ & $\overline{\mathbf{m}}$. & muh & cow \\
\hline 50 & $1 ; 08$ & bəì & Brille & glasses \\
\hline
\end{tabular}

a The status of this expression as a word can only be justified semantically.

b The word vanished after a short time, but was taken up again several days later.

c The first sound of this word was a bilabial trill.

d The word was initially uttered only once (several days between first and second production). 